\title{
Model of Working Capital Financing of Mekaar Pruducts in Sme's Empowerment Framework at PT. Permodalan Nasional Madani in Surabaya
}

\author{
Nurul Fatmawati \\ Narotama University, Surabaya \\ nurulfatmawati186@gmail.com
}

\begin{abstract}
The purpose of this study was to determine the role of microfinance / non-bank institutions in the pre-prosperous female SME empowerment program at PT. Permodalan Nasional Madani in Surabaya. This research method uses a qualitative descriptive approach, the data used in this study are primary data with internal and external data sources. This research was conducted by conducting surveys, interviews, documentation, and questionnaires on 12 respondents from a total of 30 respondents who were still active as customers at PNM Mekaar Surabaya. The results and findings of this study reveal that the joint system of working capital financing is very effective for SMEs, especially for financial institutions whose targets are pre-prosperous women. This is reflected in the average score of perceptions for 15 statements of $75.8 \%$, while each statement has a score of $62.3 \%$, therefore the reconstruction of the financing model is said to be good.
\end{abstract}

Keywords: Capital, Company, Model, Credit, Joint responsibility.

\section{INTRODUCTION}

The role of microfinance institutions as providers of financial services for SMEs and as an alternative to assisting business development and community empowerment is very important for SMEs. Important contributions Microfinance institutions can provide credit and other financial services to small entrepreneurs and low-income communities, allowing them to build their businesses sustainably. This is because the market segment of Microfinance Institutions in general is a group of SMEs which are considered by banks as not having adequate requirements, while access to capital for SMEs is a problem that cannot be met by banks.

Working capital is capital or funds needed to finance all activities, with the aim of the business being able to run in accordance with the plans that have been made. In other words capital is the funds needed to carry out all operations.

The focus of this study is to find out the working capital financing model in order to empower Umkm at PT. Permodalan Nasional Madani in Surabaya. This paper highlights a number of important factors for formulating the role of PNM's financing Mekaar:

1. How is the working capital financing model applied by PT. National Madani Permodaan in Surabaya?

2. What is the effective SME financing model at PT. Permodalan Nasional Madani in Surabaya?

3. How is the effective model of SME empowerment at PT. Permodalan Nasional Madani Surabaya?

\section{BACKGROUND}

Micro financing is a financing facility provided for the continuity of micro businesses (Indonesian Bankers Association, 2014). The micro business according to the Decree of the Minister of Finance Number 40 / KMK.06 / 2003 dated January 29, 2003, namely: "(a) Productive businesses owned by families or individuals, (b) Sales of a maximum of Rp. 100 million per year, (c) The proposed credit is a maximum of Rp. 50 million. "According to Republic of Indonesia Law Number 20 of 2008 concerning micro, small and medium enterprises that Micro Enterprises are" Productive businesses owned by individuals and / or 
individual business entities that meet the criteria for micro-enterprises as stipulated in this Act. " Classification of Micro Enterprises is as follows: "(1) Having a net worth of at most Rp50,000,000.00 (fifty million rupiahs) not including land and building of business premises; or (2) Having annual sales of no more than Rp. 300,000,000.00 (three hundred million rupiah).

According to Dr. Darsono P, (2006: 175) said that if "In debt financing, creditors do not have the right to property. If the debtor or debtor does not fulfill his obligation to pay interest and installments on the loan, the creditor has difficulty confiscating the debtor's property, the confiscation of the debtor's assets by the creditor must go through a legal process ".

Working capital financing is very important for SMEs in empowering and increasing it. UKM is a business sector that is able to play a very strategic role by making a very high contribution in encouraging a country's economic growth and progress. SMEs tend to have business systems that are flexible, prospective and feasible. However, what is owned by micro, small and medium enterprises does not make it always able to qualify for bankable credit. This is due to the absence of sufficient collateral, so there is no definite and reasonable guarantee of credit worthiness that has been established and implemented by the bank to avoid the risk of bad credit. This situation makes SMEs slow in their growth. The factors that make it slow in growth are constraints in the acquisition of working capital.

The phenomenon of credit supply lately in 2018 is increasingly circulating from various financial institutions in the community, especially in the microfinance sector. This is balanced with the demand for credit which increases every year and is proven by the proportion of credit Umkm based on the central statistical body in the years 2011-2016 as follows:

Tabel 2.1 Proportion of SME Loans Against Total Loans (Trillion Rupiah)

\begin{tabular}{|c|c|c|c|c|c|c|}
\hline \multirow{2}{*}{$\begin{array}{l}\text { Credit } \\
\text { Position }\end{array}$} & \multicolumn{6}{|c|}{ Proportion of SME Loans Against Total Loans (Trillion Rupiah) } \\
\hline & 2011 & 2012 & 2013 & 2014 & 2015 & 2016 \\
\hline Micro & 88.02 & 97.18 & 118.77 & 140.27 & 164.87 & 178.51 \\
\hline Small & 146.53 & 164.27 & 187.73 & 201.98 & 215.92 & 236.3 \\
\hline Medium & 223.61 & 264.95 & 303.53 & 329.47 & 359.01 & 367.09 \\
\hline Total UMKM & 458.16 & 526.4 & 610.03 & 671.72 & 739.8 & 781.91 \\
\hline
\end{tabular}

From the table above, it can be seen that the attractiveness of the community, especially SMEs, will use credit capital services for the development of their business, which is getting higher every year. The proportion of credit in 2016 has reached 781.91 (trillion rupiah). This further reinforces the perception that working capital is very important for SMEs in developing their business and increasing their income. With the many financial institutions in circulation, it will greatly help Umkm in increasing its working capital, so that Umkm empowerment is not only a mere discourse, but can be realized well.

\section{METHODOLOGY}

This research was conducted in the form of qualitative descriptive. Qualitative research methods can be interpreted as research methods based on positive philosophy, used to discuss natural objects that are contradicted by which instruments are located, data mining techniques are combined, data obtained is qualitative, data analysis is inductive / qualitative, and qualitative research results are more consider the meaning of generalization. This research was conducted on SMEs in Kalisari Surabaya, which are still active customers and have joined since 2016 - until now at PT. Madani Kenjeran National Permodalan Branch in Surabaya. The data collection method used is primary data with internal and external data sources. Primary data is obtained through observation, direct interviews with informants, documentation, and questionnaires. 


\section{RESULT AND DISCUSSION}

\subsection{Description of Research Results}

PNM Mekaar is a state-formed business entity in the SME's empowerment program by channeling state money to underprivileged mothers who have small businesses. The original business entity of the country in Indonesia since the time of the monetary crisis in Indonesia. While the flagship product of PT. Permodalan Nasional Madani besides PNM Mekaar is PNM Ulaam or "Micro Capital Service Unit". ULaMM is a capital loan service for micro and small businesses that supports assistance to develop it. UlaMM is a new model or breakthrough for PNM because the distribution of funding is done directly to individuals or loans to Business Entities (PT, CV, Firm, etc.).

In the Mekaar PNM financing program, the AO (Account Officer) agent is responsible for providing assistance and guidance containing a culture full of honesty, discipline, hard work, harmony, family and mutual cooperation. Mekaar services can help women, micro-businesses, with families having a maximum level of income per capita of US \$ 1.9 per day or Rp. 800,000 per month, and meets the conditions of home conditions (Cashpor Index). The first venture capital funding provided is Rp. 2,000,000 (two million rupiah). Blooming funding does not require the physical requirements needed to hire a group that requires a budget preparation process and a weekly group meeting (PKM). One group consists of at least 2 (two) sub-groups, a maximum of 6 (six) sub-groups where 1 (one) sub-group consists of at least 5 (five) investments and a maximum of 8 (combined) funds, and 1 group consists of a minimum 10 (ten) finances and a maximum of 30 (thirty) money. Each group is led by 1 group leader, a group meeting must be held every week and together with the weekly group meeting place (PKM).

Mekaar Products (Fostering a Family Welfare Economy) is an empowerment service through groupbased financing for underprivileged Super Micro Business actors, through: Improving financial management to realize family aspirations and welfare, Financing business capital without collateral, Habitual culture of saving, Increasing entrepreneurial competence and business development.

The products offered are related to accounts payable with the distribution of working capital financing as follows:

1) Initial financing product for customers is Rp.2,000,000 in installments per week Rp.50,000 for 50 weeks. - There is no guarantee of being able to become a customer, it's just enough to submit the complete document requirements such as a photocopy of your husband's wife's ID card, family card, etc. If the prospective customer of his house is still in contract status, he must attach a domicile.

2) After 1 year running, customers can take financing in the second year with a cycle increase of Rp. 500,000 - Rp.1,000,000 that will be offered by PNM Mekaar. Financing provided is a maximum of Rp.5,000,000.

3) Actually there is a product of Rp.2,000,000 in installments of Rp.90,000 per week for 25 weeks. This product has no interest due to objections in the installments, so products that are often offered are Rp.2,000,000 in installments per week Rp.50,000 for 50 weeks.

The General Stages of Mekaar's Financing Process:

1) Socialization of SMEs

The socialization process is the first stage of the financing process. In the socialization activity, it is also determined the determination of targets which plays an important role in identifying women who fulfill the terms and conditions as their financing targets. It must be ensured that these women are truly from preprosperous families, the only selected areas that really have high numbers of poor / poor families. Mekaar socialization is divided into 2 (two) stages, namely, socialization at the level of the local government apparatus and customer level socialization.

2) Financing Feasibility Test

Feasibility testing is an activity to "photograph" the prospective socio-economic conditions that include:

- The condition of the house is not more than 12 meters and the level of income is a maximum of Rp.800,000

- Information is obtained through visits to prospective customers and interviews using questionnaires.

- Interviews are conducted by AO at the prospective customer's home and should be attended by prospective customers for married people and family heads and wives so that accurate data can be obtained and avoid repeated interviews that can waste time.

The due diligence procedure contains the following:

a) General Criteria

b) Feasibility Test Preparation (UK)

c) Feasibility Test (UK) 
d) Responsible Person / Official Related to Feasibility Test (UK)

e) The role of SAO

3) Preparation of SME Financing

It is an activity that must be followed by every prospective customer who has been declared to have passed the feasibility test (UK), after the time and place of implementation (PP) has been determined, the prospective customer must attend and attend the PP.

4) Disbursement of SME Financing

Disbursement of funding can be done immediately after going through the stages of feasibility testing.

5) SME Weekly Group Meetings

The weekly meeting must be held, this is because in order to facilitate the establishment of cooperation between companies and SMEs in the return of credit capital.

Table 1.Mekaar's Financing Process

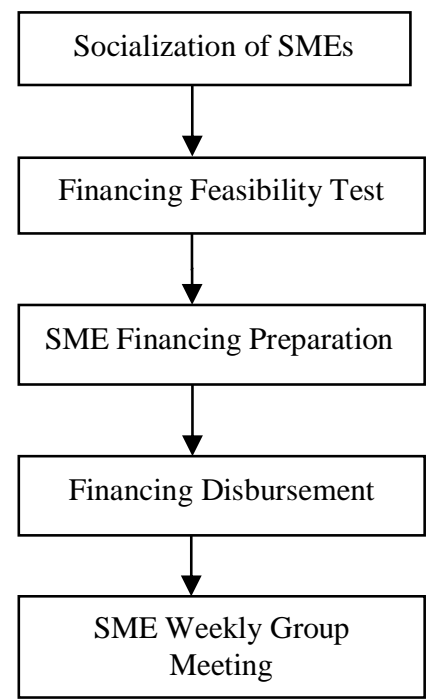

(Source: processed by the author)

Based on the above data, the author conducted the AO party who was conducting socialization and guidance to pre-prosperous women Umkm, then the data has similarities with the results of direct interviews with Ms. Ida as (group leader) in Kalisari Surabaya who joined PT. Permodalan Nasional Madani Kenjeran Branch Surabaya, he stated that he had received 3 years of venture capital financing from PNM Mekaar. The first financing was given a loan of Rp. 2,000,000 with a 2\% interest agreement per month and a credit installment of Rp.50,000 per week (weekly collective payment) which must be attended by all members of Ibu Ida's group which will be accompanied by AO from PNM. The increase in the cycle that will be obtained by SMEs is Rp.1,000,000 after passing the first cycle and has already paid off. Every increase in the cycle, the financing increases and the credit installments per week also increase according to the financing of business capital received by Umkm. This weekly meeting has been scheduled and agreed upon by AO and Umkm, for the time the association follows PNM's schedule, starting at 08.00-14.00, because the AO must deposit the PKM proceeds to FAO.

In this study the respondents were taken randomly in each sub-type of business. Overall traders have the same criteria that do not make much difference to the results of the questionnaire questionnaire. The total respondents that the author made were there were 12 traders from 30 traders with details as follows: 
Table 2.Profile of Respondents

\begin{tabular}{|c|l|c|c|}
\hline NO & RESPONDENT & TOTAL & PERCENTAGE \\
\hline 1 & Grocery Traders & 4 & $33.40 \%$ \\
\hline 2 & Food and beverage traders & 4 & $33.40 \%$ \\
\hline 3 & Craft traders & 2 & $16.60 \%$ \\
\hline 4 & Online Clothes Merchants & 2 & $16.60 \%$ \\
\hline & TOTAL & $\mathbf{1 2}$ & $\mathbf{1 0 0 \%}$ \\
\hline
\end{tabular}

(Source: processed by the author )

From the detailed data above can be explained in detail that:

Each respondent will be given instrument questions that represent the research data needs. Respondents' answers will be represented by the answer "YES" or "NO" for each question from this research instrument. The answer will be able to represent the data that will be needed for each question. The composition of respondents in the research is expected to be able to represent each type of business. Randomly selected respondents will be observed periodically to meet the degree of trust in the data that has been given. "Yes" and "no" answers with positive meaning from 12 respondents will be grouped into 3 categories a) low category if the answer "yes" is less than 50\%, b) medium category if the answer is "yes" between $50-74 \%$, c) high if the answer is between $75-100 \%$. Referring to the "yes" answer from 12 respondents.

The following is a list of collected questionnaire data:

Table 3.Table of Results of the Guttman Scale Questionnaire

\begin{tabular}{|c|c|c|c|c|c|c|}
\hline \multirow{2}{*}{ KODE } & \multirow{2}{*}{ QUESTION } & \multirow{2}{*}{ Total } & \multicolumn{2}{|c|}{ ANSWER } & \multicolumn{2}{|c|}{ PRESENTASE } \\
\hline & & & YES & $\mathrm{NO}$ & YES & $\mathrm{NO}$ \\
\hline \multicolumn{7}{|c|}{ Socialization of PT. Permodalan Nasional Madani } \\
\hline 1 & $\begin{array}{l}\text { Is the socialization provided by PT. } \\
\text { Permodalan Nasional Madani is good } \\
\text { enough? }\end{array}$ & 12 & 10 & 2 & $83 \%$ & $17 \%$ \\
\hline 2 & $\begin{array}{l}\text { Are there obstacles in the process of applying } \\
\text { for funding at PNM? }\end{array}$ & 12 & 5 & 7 & $42 \%$ & $58 \%$ \\
\hline \multicolumn{7}{|c|}{ Feasibility Test of PT. Permodalan Nasional Madani } \\
\hline 3 & $\begin{array}{l}\text { Are the requirements of PNM difficult for } \\
\text { SMEs? }\end{array}$ & 12 & 3 & 8 & $25 \%$ & $67 \%$ \\
\hline 4 & $\begin{array}{l}\text { Have you ever borrowed venture capital to } \\
\text { anyone other than PNM? }\end{array}$ & 12 & 6 & 6 & $50 \%$ & $50 \%$ \\
\hline 5 & $\begin{array}{l}\text { Could your submission be rejected when the } \\
\text { document is complete? }\end{array}$ & 12 & 7 & 6 & $58 \%$ & $50 \%$ \\
\hline 6 & $\begin{array}{l}\text { Does the process of testing the feasibility of } \\
\text { PNM take a long time? }\end{array}$ & 12 & 4 & 8 & $33 \%$ & $67 \%$ \\
\hline \multicolumn{7}{|c|}{ Preparation of MSME Financing PT. Permodalan Nasional Madani } \\
\hline 7 & $\begin{array}{l}\text { Is the preparation of funding in the } \\
\text { development of SMEs (Schools of Women) } \\
\text { quite good? }\end{array}$ & 12 & 10 & 2 & $83 \%$ & $17 \%$ \\
\hline 8 & $\begin{array}{l}\text { Are there obstacles in the process of } \\
\text { disbursing funds at PNM? }\end{array}$ & 12 & 3 & 9 & $25 \%$ & $75 \%$ \\
\hline 9 & $\begin{array}{l}\text { Is it true that funds cannot be disbursed } \\
\text { before all complete group members are in } \\
\text { PKM? }\end{array}$ & 12 & 12 & 0 & $100 \%$ & $0 \%$ \\
\hline \multicolumn{7}{|c|}{ Pencairan Pembiayaan \& PKM PT. Permodalan Nasional Madani } \\
\hline 10 & $\begin{array}{l}\text { Is the process of disbursing funds exceeding } \\
\text { the specified agreement? }\end{array}$ & 12 & 1 & 11 & $100 \%$ & $92 \%$ \\
\hline
\end{tabular}




\begin{tabular}{|c|l|c|c|c|c|c|}
\hline 11 & $\begin{array}{l}\text { Do you mind the loan interest offered by } \\
\text { PNM? }\end{array}$ & 12 & 11 & $8 \%$ \\
\hline 12 & $\begin{array}{l}\text { Do you use your own capital in the initial } \\
\text { establishment of the business? }\end{array}$ & 12 & 10 & 2 & $83 \%$ & $17 \%$ \\
\hline 13 & $\begin{array}{l}\text { In your opinion, are the business capital loans } \\
\text { offered by PNM quite helpful and beneficial } \\
\text { for SMEs? }\end{array}$ & 12 & 11 & 1 & $92 \%$ & $8 \%$ \\
\hline 14 & $\begin{array}{l}\text { Are there obstacles in managing credit capital } \\
\text { that PNM has given? }\end{array}$ & 12 & 7 & 5 & $58 \%$ & $42 \%$ \\
\hline 15 & $\begin{array}{l}\text { Is there an increase in productivity in the } \\
\text { business after obtaining PNM credit business } \\
\text { capital? }\end{array}$ & 12 & 8 & 4 & $67 \%$ & $33 \%$ \\
\hline 16 & $\begin{array}{l}\text { Is there a difference in running a business } \\
\text { before and after receiving business credit } \\
\text { capital from PNM? }\end{array}$ & 12 & 9 & 3 & $75 \%$ & $25 \%$ \\
\hline 18 & $\begin{array}{l}\text { Is it true that after obtaining credit business } \\
\text { capital, your income will increase? }\end{array}$ & 12 & 10 & 2 & $83 \%$ & $17 \%$ \\
\hline 19 & $\begin{array}{l}\text { In your opinion, is the system financing } \\
\text { model with the PNM jointly effective? }\end{array}$ & 12 & 9 & 3 & $75 \%$ & $25 \%$ \\
\hline $\begin{array}{l}\text { In your opinion, can PNM's efforts in the } \\
\text { joint financing of microfinance systems } \\
\text { empower SMEs in Surabaya? }\end{array}$ & 12 & 7 & 5 & $58 \%$ & $42 \%$ \\
\hline $\begin{array}{l}\text { In your opinion, can the PNM financing } \\
\text { thodel really empower SMEs according to }\end{array}$ & 12 & 7 & 5 & $58 \%$ & $42 \%$ \\
\hline
\end{tabular}

(Source: processed by the author )

Table 4.Recapitulation Table of the results of the PNM PNM financing model questionnaire

\begin{tabular}{|c|l|c|c|c|}
\hline \multirow{2}{*}{ KODE } & \multicolumn{1}{|c|}{ QUESTION GROWTH } & \multicolumn{2}{|c|}{ REAL CONDITION OF SMEs } \\
\cline { 3 - 4 } & & Low & Medium & High \\
\hline 1 & $\begin{array}{l}\text { Is the socialization provided by PT. Permodalan } \\
\text { Nasional Madani is good enough? }\end{array}$ & & $83 \%$ \\
\hline 2 & $\begin{array}{l}\text { Are there obstacles in the process of applying for } \\
\text { funding at PNM? }\end{array}$ & $58 \%$ & $67 \%$ & \\
\hline 3 & Are the requirements of PNM difficult for SMEs? & $50 \%$ & \\
\hline 4 & $\begin{array}{l}\text { Have you ever borrowed venture capital to anyone other } \\
\text { than PNM? }\end{array}$ & $50 \%$ & & \\
\hline 5 & $\begin{array}{l}\text { Could your submission be rejected when the document } \\
\text { is complete? }\end{array}$ & & $67 \%$ & \\
\hline 6 & $\begin{array}{l}\text { Does the process of testing the feasibility of PNM take } \\
\text { a long time? }\end{array}$ & & & \\
\hline 7 & $\begin{array}{l}\text { Is the preparation of funding in the development of } \\
\text { SMEs (Schools of Women) quite good? }\end{array}$ & & $75 \%$ \\
\hline 8 & $\begin{array}{l}\text { Are there obstacles in the process of disbursing funds at } \\
\text { PNM? }\end{array}$ & & & $100 \%$ \\
\hline 9 & $\begin{array}{l}\text { Is it true that funds cannot be disbursed before all } \\
\text { complete group members are in PKM? }\end{array}$ & & & \\
\hline
\end{tabular}




\begin{tabular}{|c|c|c|c|}
\hline 10 & $\begin{array}{l}\text { Is the process of disbursing funds exceeding the } \\
\text { specified agreement? }\end{array}$ & & $92 \%$ \\
\hline 11 & Do you mind the loan interest offered by PNM? & & $92 \%$ \\
\hline 12 & $\begin{array}{l}\text { Do you use your own capital in the initial establishment } \\
\text { of the business? }\end{array}$ & & $83 \%$ \\
\hline 13 & $\begin{array}{l}\text { In your opinion, are the business capital loans offered } \\
\text { by PNM quite helpful and beneficial for SMEs? }\end{array}$ & & $92 \%$ \\
\hline 14 & $\begin{array}{l}\text { Are there obstacles in managing credit capital that PNM } \\
\text { has given? }\end{array}$ & $58 \%$ & \\
\hline 15 & $\begin{array}{l}\text { Is there an increase in productivity in the business after } \\
\text { obtaining PNM credit business capital? }\end{array}$ & $67 \%$ & \\
\hline 16 & $\begin{array}{l}\text { Is there a difference in running a business before and } \\
\text { after receiving business credit capital from PNM? }\end{array}$ & $75 \%$ & \\
\hline 17 & $\begin{array}{l}\text { Is it true that after obtaining credit business capital, } \\
\text { your income will increase? }\end{array}$ & & $83 \%$ \\
\hline 18 & $\begin{array}{l}\text { In your opinion, is the system financing model with the } \\
\text { PNM jointly effective? }\end{array}$ & & $75 \%$ \\
\hline 19 & $\begin{array}{l}\text { In your opinion, can PNM's efforts in the joint } \\
\text { financing of microfinance systems empower SMEs in } \\
\text { Surabaya? }\end{array}$ & $58 \%$ & \\
\hline 20 & $\begin{array}{l}\text { In your opinion, can the PNM financing model really } \\
\text { empower SMEs according to their objectives? }\end{array}$ & $58 \%$ & \\
\hline
\end{tabular}

(Source: processed by the author)

Based on respondents' profiles and answers. It can be concluded that the poor women Umkm are very happy to accept working capital financing offered by PT. Permodalan Nasional Madani in Surabaya. According to SMEs with this funding, not only is the capital increased, but the income of SMEs also increases. The requested requirements are not too complicated so that they can be reached by SMEs. SMEs strongly agree with this company's goal, namely to channel financing to underprivileged women in the context of empowering SMEs in Surabaya. However, there is a time limit in weekly collective payments (PKM) that makes financing less effective, while limiting age for loan recipients is also an obstacle in this financing. According to SMEs, weekly payments should be divided into two stages, namely morning and evening because some of the Umkm also work in the morning, so all Umkm can participate in weekly weekly / collective payments. As for age restrictions, it may be possible to extend it for another 2 years, namely the age limit for receiving loans up to 60 years. This is because entrepreneurs who are diligent and really have long been SMEs, mostly also from SMEs who are 60 years old and even up.

\subsection{Discussion of Research Results \\ 4.2.1 Application of Mekaar's PNM Capital Financing Model}

The financing model applied by PT. Permodalan Nasional Madani is a model that uses a joint responsibility system. The system of joint responsibility is the obligation to bear on the part of those who owe, when they are all obliged to do the same thing, such that one can be sued for the whole, and fulfillment by one frees the other owed people to the debtor. In the form of passive joint responsibility consists of the following factors (Gunawan Widjaja and Kartini Mulyadi, 2002: 118-119):

a. There are two or more debtors;

b. Each debtor is obliged for the same achievement, namely each for all achievements;

c. Repayment by a debtor frees other debtors;

b. The debt from joint liability debtors has the same basis or basis.

This joint liability guarantee can arise with conditions that must be desired by the parties concerned and never denied, it must be expressly stated (J Satrio, 1999: 335).

In PNM, the responsibility system is very applicable to SMEs that are still actively receiving funding. SMEs that are categorized as joint responsibility, namely Umkm who often do not take part in PKM and are absent from their credit payments, if they are absent, SMEs will miss the boundary and there is no clarity, PNM will close the financing to SMEs whose members are considered to be jointly responsible it must pay off all the funding that has been given by PNM. PNM also implements an achievement system 
by providing points + every day for SMEs who always participate in weekly collective payment activities (PKM) and will provide further product offerings, with an increase in the limit of the initial loan capital of Rp.500,000 to Rp. 1,000,000 after the initial loan has been completed.

Criteria for SMEs that can join PNM are:

- Pre-prosperous women

- Age 18 - 58 years

- Has an income of no more than Rp. 800,000

- The index of the house does not exceed 12 meters

As for the Mekaar PNM financing process, namely:

- SME socialization

- SME Credit Feasibility Test

- Financing Preparation

- Financing Disbursement

- Weekly Collective Payment Association (PKM)

\subsubsection{Stages of Mekaar PNM Financing Reconstruction Model}

Model reconstruction, the stage of reducing the relevant problems to form a working capital financing model for pre-prosperous women, so that it can be used for an effective and efficient financing model from the previous model of financing application.

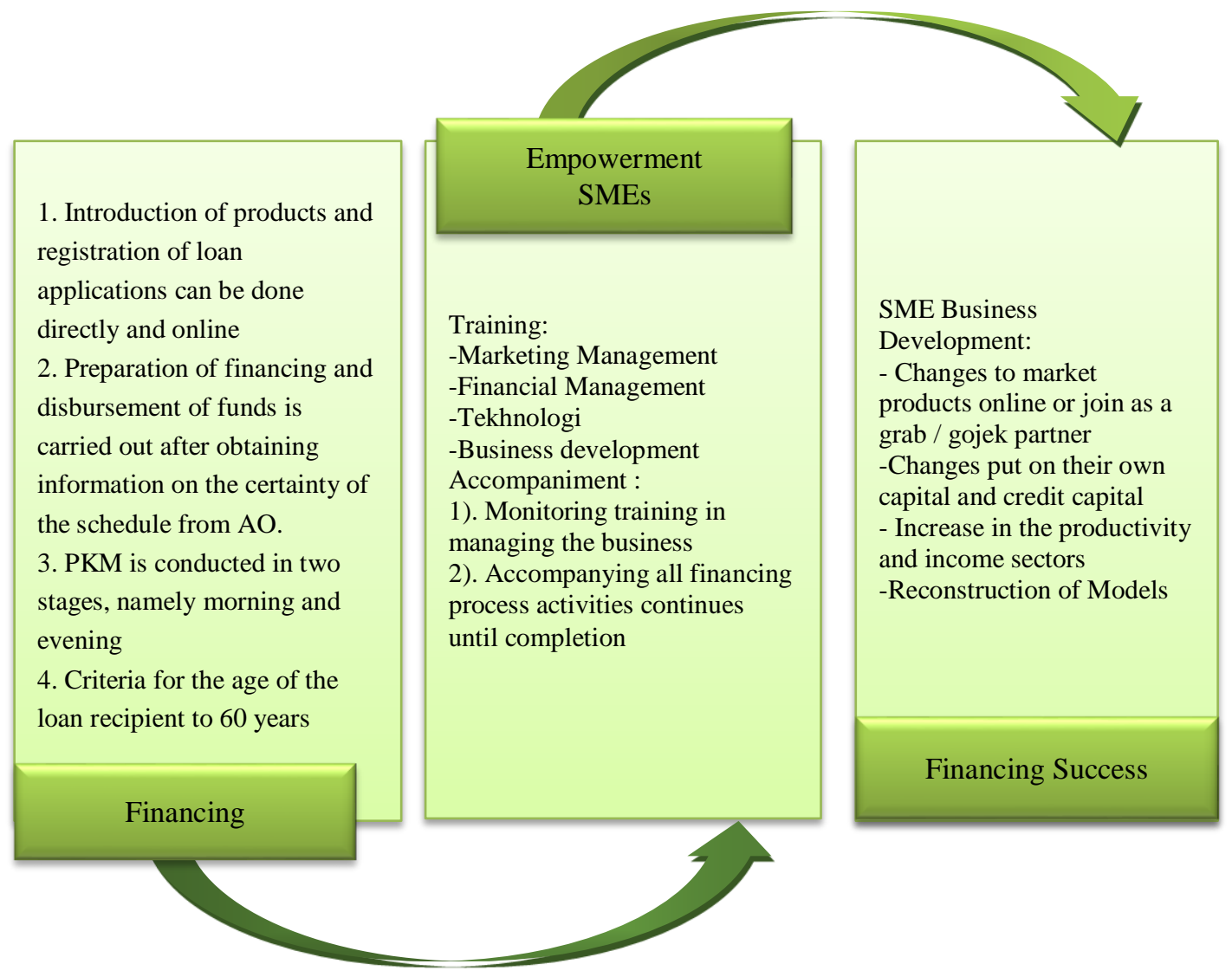

Model effectiveness testing is a situation reconstruction that is considered as a practical and efficient way to express what is designed in the model in accordance with the financing model expected by SMEs. Stage testing models include:

- Identify existing indicators

- Determine the type of scale and the measurement results with an interval scale of five levels

- Designing questionnaires related to disclosure of perceptions of business actors

- Disseminate questionnaires to 12 respondents with purposive sampling

- Tabulation of data on respondents' answers

- Analyze in depth about the perceptions of business actors related to 
Following are the respondents' perceptions of the PNM financing model Mekaar with a Likert scale made by the author to test the effectiveness of the reconstruction model above. Respondents' perceptions were important in this study to obtain an effective model of the application of the previous financing model implemented by PNM Mekaar. This is because those who were respondents in this study were Umkm who were aware of PNM's PNM financing and were having capital loans to PNM.

Table 5.Respondents' Perception of the Mekaar PNM Financing Model

\begin{tabular}{|c|c|c|c|c|c|c|c|}
\hline \multirow{2}{*}{ CODE } & \multirow{2}{*}{ ITEM QUESTIONS } & \multicolumn{5}{|c|}{ Respondent's answer } & \multirow{2}{*}{$\begin{array}{l}\text { Value } \\
(\%)\end{array}$} \\
\hline & & 1 & 2 & 3 & 4 & 5 & \\
\hline 1 & Financing products can be accessed online & - & - & 1 & 5 & 6 & 73.0 \\
\hline 2 & Disbursement of funds can be done 1 day & - & - & 2 & 3 & 7 & 76.3 \\
\hline 3 & Weekly group meetings are not time-limited & - & - & 1 & 4 & 7 & 77.3 \\
\hline 4 & $\begin{array}{l}\text { Age criteria are not limited and adjusted for } \\
\text { real business }\end{array}$ & - & - & 2 & 2 & 8 & 80.7 \\
\hline 5 & $\begin{array}{l}\text { Maximum loan limits do not add a long } \\
\text { period of weekly collective payments }\end{array}$ & - & - & 3 & 5 & 4 & 62.3 \\
\hline 6 & $\begin{array}{l}\text { Marketing Management Training is useful } \\
\text { for Umkm business development }\end{array}$ & - & - & 1 & 5 & 6 & 73.0 \\
\hline 7 & $\begin{array}{l}\text { Financial Management Training is useful for } \\
\text { managing SME capital in order to avoid } \\
\text { consumptive use }\end{array}$ & - & - & 2 & 3 & 7 & 76.3 \\
\hline 8 & $\begin{array}{l}\text { Debriefing will be a useful technology for } \\
\text { SME business development }\end{array}$ & - & - & 3 & 2 & 7 & 75.3 \\
\hline 9 & $\begin{array}{l}\text { The mentoring program can improve the } \\
\text { competence of SMEs in marketing their } \\
\text { products }\end{array}$ & - & - & 2 & 4 & 6 & 72.0 \\
\hline 10 & $\begin{array}{l}\text { The mentoring program can improve the } \\
\text { competence of SMEs in managing their } \\
\text { capital }\end{array}$ & - & - & 1 & 4 & 7 & 77.3 \\
\hline 11 & $\begin{array}{l}\text { The mentoring program can improve the } \\
\text { competency of SMEs in broader marketing } \\
\text { through online }\end{array}$ & - & - & 2 & 3 & 7 & 76.3 \\
\hline 12 & $\begin{array}{l}\text { The mentoring program can improve the } \\
\text { competence of SMEs in developing business } \\
\text { management }\end{array}$ & - & - & 1 & 3 & 8 & 81.7 \\
\hline 13 & $\begin{array}{l}\text { Effective financing, training and mentoring } \\
\text { can increase the success of financing }\end{array}$ & - & - & 1 & 4 & 7 & 77.3 \\
\hline 14 & $\begin{array}{l}\text { Effective funding, training and mentoring } \\
\text { can increase Umkm productivity }\end{array}$ & - & - & 2 & 4 & 6 & 72.0 \\
\hline 15 & $\begin{array}{l}\text { Effective financing, training and mentoring } \\
\text { can increase SME income }\end{array}$ & - & - & 1 & 2 & 9 & 86.0 \\
\hline & Total Value of Respondents' perceptions & - & - & - & - & - & 75.8 \\
\hline
\end{tabular}

(Source: processed by the author)

The table above shows that "the formulation of the Mekaar PNM financing model has been very well perceived by the respondents. This can be seen from the average score of perception for 15 statements amounting to $75.8 \%$, while each statement has the lowest score of $62.3 \%$, therefore the reconstruction of the financing model is in a position of good category because the average perception is above $60 \%$. This is 
in accordance with the conditions in the field that Umkm requires knowledge and online submission registration so that Umkm can more easily find out the loan calculation and interest. Umkm also hopes for training and assistance in developing its business both in terms of product marketing by utilizing IT, training in business development strategies, and financial management of its capital, so that Umkm can map its personal capital and finance its business capital to be managed properly and wisely so avoid the use of consumptive financing.

\section{CONCLUSION AND SUGGESTION}

The availability of working capital in business development is indeed very important, especially for SMEs. The role of the government and bank and non-bank financial institutions is needed by the people who become SMEs to increase the volume of productivity and income. From the results of the above research shows that the financing of working capital with a joint responsibility system applied by PT. Permodalan Nasional Madani is quite helpful in the welfare of SMEs, but in the financing model requires some additional training and effective assistance to support government program policies in empowering SMEs. This is evidenced by the results of the perceptions of respondents who are still joining PT.Permodalan Nasional Madani in Surabaya. The success of the UKM actors in Kalisari Surabaya can be seen from the average score of perception for 15 statements of $75.8 \%$, while each statement has the lowest score of $62.3 \%$, therefore the reconstruction of the financing model is in the position of a good category because the average perception is above $60 \%$.

\section{Suggestion}

The role of the government and banking is very important in order to realize increasing SMEs in Indonesia. The suggestions for the Government and SMEs are:

1). The government always encourages banks to continue to be able to channel funds to the community in order to realize one of the government programs to increase state income with the many SMEs.

2). Banking in channeling credit funds to SMEs must be more comprehensive and equitable in disseminating information on credit services to start businesses and business development for SMEs. The interest offered by the BANK should not be burdensome for SMEs, so that the interest of business actors can increase.

3). For SMEs, it is advisable to be more careful in debt and use funds properly. Due to the use of unhealthy funds, it will run the risk of bankruptcy in its business. The capital itself is ideally $60 \%$, and external funding is $40 \%$, this must be truly controlled by SME actors. As for the risks that will arise in the use of funds that are not good, such as using funds that should be for business but also used to fulfill basic needs, it will result in the inability to pay debts, and the business will also experience bankruptcy.

\section{REFERENCES}

[1] M. B. Nizaruddin Wajdi, Y. C. Ummah, and D. E. Sari, "UKM Development Business Loan," IJEBD (International J. Entrep. Bus. Dev., vol. 1, no. 1, p. 99, 2017.

[2] I. S. E. Made Siti Sundari1), Mintarti Ariani2), "PEMBERDAYAAN USAHA MIKRO KECIL MENENGAH (UMKM) PENGUSAHA KRIPIK DAN ONDE-ONDE KHAS MOJOKERTO Made," J. Bus. Stud., vol. 2, no. 2, pp. 121-132, 2017.

[3] S. R. I. Marwanti and I. D. W. I. Astuti, "Melalui Pengembangan Kewirausahaan Keluarga," Model Pemberdaya. Peremp. MISKIN MELALUI Pengemb. KEWIRAUSAHAAN Kel. MENUJU Ekon. Kreat. DI KABUPATEN KARANGANYAR SRI, vol. 9, no. 1, pp. 134-144, 2012.

[4] Suparnyo, A. Wicaksono, and W. Ariyani, "Model Pemberdayaan Usaha Mikro Kecil dan Menengah (UMKM) melalui Program Corporate Social Rresponsibility (CSR) pada Industri Rokok di Kudus,” J. Sos. Budaya, vol. 6, no. 2, pp. 29-39, 2013.

[5] A. Efianingrum, “METODE PENELITIAN KUALITATIF DAN KUANTITATIF,” pp. 1-8.

[6] S. E. Mulyono, "Model Pemberdayaan Masyarakat untuk Peningkatan Literasi Berbasis Kewirausahaan Usaha Mandiri Melalui PKBM Di Kota Semarang,” J. Nonform. Educ., vol. 1, no. 
1, pp. 1-8, 2015.

[7] L. Tahunan, "PNM Hadir Sejahterakan UMK Indonesia Sanggahan dan Tentang Laporan Tahunan Pnm 2017 About Pnm 2017 Annual Report,” 2017.

[8] A. K. Anam, "Identifikasi Model, ......... (A.Khoirul Anam\& Aida N.),” vol. 01, no. 01, pp. 46-53, 2015.

[9] nunung ghoniyah Siti anif, "Model Pemberdayaan Dan Peningkatan Kinerja Usaha Kecil Menengah (Ukm)," Semnas Fekon 2016, no. 2011, pp. 50-57, 2016.

[10] "INFO DATA PNM." .

[11] غلامحسين .ث "umkm,” p. 302, 1385.

[12] Sutopo Indi, "PRODUKTIVITAS DAN KETAHANAN BISNIS INDUSTRI KECIL (Studi Empiris Industri Batik Tulis Trusmi Kecamatan Plered Kabupaten Cirebon)," Din. Keuang. dan Perbank., vol. 3, no. 1, pp. 102-112, 2011.

[13] D. Komisioner and O. Jasa, RANCANGAN PERATURAN OTORITAS JASA KEUANGAN NOMOR IPOJK.05/2017 TENTANG PENGAWASAN PT PERMODALAN NASIONAL MADANI (PERSERO) DENGAN. 2017.

[14] R. Syahputra, "Pengertian Pembiayaan,” Blog. 2013.

[15] E. Steelyana, "Perempuan dan Perbankan: Sebuah Tinjauan Tentang Peran Inklusi Keuangan terhadap Pengusaha UMKM Perempuan di Indonesia,” The Winners, vol. 14, no. 2, p. 95, 2017.

[16] N. K. Sumbawati, I. Fitryani, and A. Budiman, "Pengaruh Pemberian Kredit Terhadap Pendapatan Pedagang Usaha Kecil Dan Menengah ( Studi Kasus PT . Pegadaian ( Persero ) Unit Pelayanan Cabang Moyo Hilir ) Tahun 2014-2016," J. Ekon. dan Bisnis Vol 15 No 1, April 2018 Pengaruh, vol. 15, no. 1, pp. 1-8, 2018.

[17] A. Asnahwati, "Model Tata Kelola Keuangan Usaha Mikro Kecil Menengah ( UMKM ) Wanita," Daya Saing, vol. 4, no. 2, pp. 259-268, 2018.

[18] T. Afkar, "Pengaruh Pembiayaan Usaha Mikro, Kecil, Menengah (Umkm), Dan Kecukupan Modal Terhadap Kemampuan Mendapatkan Laba Dari Aset Perbankan Syariah Di Indonesia,” al-Uqud J. Islam. Econ., vol. 1, no. 2, p. 183, 2017.

[19] Wahba, "MODAL KERJA TERHADAP PROFITABILITAS USAHA," 196 e J. Katalogis, hlm 195-203, vol. Volume $6 \mathrm{~N}$.

[20] S. Manjula, T. Nadu, and T. Nadu, "Analysis of Working Capital Efficiency of Vegetable Oil Companies in India,” vol. 4, no. 2, pp. 994-1003, 2018.

[21] M. I. Roy, "Indrajit Roy:," Anal. PERTUMBUHAN PEMBIAYAAN UMKM TERHADAP PERTUMBUHAN LABA BERSIH BPRS DI Indones. Mochamad, vol. 8, no. 1, pp. 47-58, 2017.

[22] A. Agro, L. Tbk, T. Baru, and R. Abesty, “Analisis Efektivitas Modal Kerja Terhadap Profitabilitas dan Aktivitas Pada PT Profitabilitas dan Aktivitas Pada PT Asta Agro Lestari Tbk dan PT Tunas Baru Lampung,” no. August 2014, 2018.

[23] M. A. Prayogi and L. H. Siregar, "Pengaruh Pembiayaan Mikro Syariah Terhadap Tingkat Perkembangan Usaha Mikro Kecil Menengah ( UMKM ) The Influence of Sharia Micro Financing On The Development Rate of Micro Small and Medium Enterprises ( UMKM )," vol. 17, no. 2, pp. 121-131, 2017.

[24] P. Usaha, N. Pada, and P. T. Bank, "Pengaruh Pembiayaan Modal Kerja ......... Erdah Litriani dan Leni Leviana PENGARUH PEMBIAYAAN MODAL KERJA TERHADAP Abstract This study aims to investigate the Working Capital Financing Effect Against Revenue Customer At PT . Bank Syariah Mandiri Branch Of,” vol. 3, no. 2, pp. 123-140, 2017.

http://eprints.uny.ac.id/21637/4/BAB\%20III.pdf 
http://www.bps.co.id/ www.pnm.co.idhttp://bumn.go.id/pnm/halaman/41/tentang-perusahaan.html

https://www.antaranews.com/berita/713566/menteri-bumn-beri-pembekalan-4000-agen-mekaar-pt-pnm

https://ekonomi.kompas.com/read/2018/01/16/185417226/akhir-tahun-2017-permintaan-kredit-barumelonjak. 